\title{
Obituaries
}

\section{RONALD TAYLOR HEYLINGS}

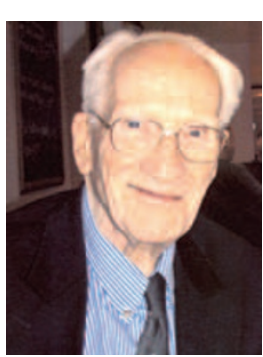

Dr Ronald Taylor

Heylings, former Senior Lecturer in the School of Dentistry, died on 28 January 2009.

Born in Batley, West Yorkshire on 15 November 1917, Dr Heylings graduated in dentistry from Leeds in 1940. He then served for five years in the Army Dental Corps. He treated soldiers returning from Dunkirk, many suffering from acute ulcerative gingivitis, which was one of the factors that triggered his research interest in this area.

Dr Heylings returned to Leeds in 1946 to take a medical degree, graduating $\mathrm{MB}$ ChB in 1948. A gifted sportsman, he represented his university in athletics, swimming, water polo, boxing and rugby and played for the Leeds Medicals Rugby Club for many years.

Following two years at St Bartholomew's Hospital, London, where he was Senior Hospital Dental Officer, Dr Heylings was appointed Lecturer in the Dental School at Leeds in 1951, becoming the School's first clinical lecturer in periodontology and developing a successful and thriving clinical department in this specialty. He was promoted to Senior Lecturer in 1968 and was awarded honorary Consultant status by the local Health Authority at the same time. He was instrumental in the creation of the school for dental hygienists in Leeds.

Despite an intensive clinical load, Dr Heylings maintained a research interest in the bacteriology and pathology of periodontal diseases, and in 1969, was awarded a PhD for his work on the role of micro-organisms in the control of periodontal disease.

For many years he presented a table demonstration on periodontology and electron microscopy subjects at the Annual General Meeting of the BDA and, during these years, organising Leeds Dental Alumni Lunches at the Dental Association AGM.

On retirement in September 1983 Dr Heylings continued as an active Rotarian and keen golfer and for many years organised an annual reunion golf match for past and present members of the Leeds Medicals Rugby Club. He enjoyed playing chess and bridge with friends and family and lived independently until the end of his life.

Dr Heylings' beloved wife Betty died in 1992. He is survived by his daughters Jillian and Judith and their families with whom he held a very close relationship.

M. Kellett

\section{DON FOSTER}

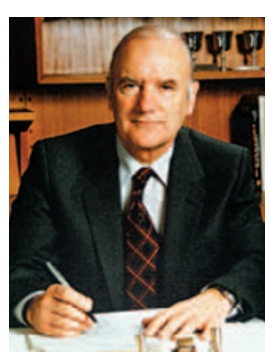

Thomas Donald
(Don) Foster was
born in 1926 in the
Hockley area of Bir-
mingham. He died
after a long illness,
courageously borne,
on 4 January 2009.
Don went to

Handsworth Grammar School but his education was interrupted by the outbreak of war and he was evacuated to the seaside village of Instow, North Devon. He left school at the age of 15 with the School Certificate. He sought an apprenticeship and by chance was sent for interview at the Department of Dental Engineering at the Birmingham Medical School, where he trained for four years to become a dental technician. He was then
Obituaries should be submitted by email to Kate Maynard at k.maynard@nature.com.

All submitted obituaries should be 350 words maximum in length (apart from obituaries for past presidents of the BDA where the length should be 700-800 words) Content of the obituary is down to the individual author, and the approval of the family should be given for the obituary prior

to submission to the $B D J$.

called up for national service in the RAF where he worked as a dental mechanic.

After demobilisation he applied and was admitted to the School of Dentistry at Birmingham University, graduating in 1953. Here he met his wife-to-be Vera, allegedly over a cadaver in the dissecting room, an inauspicious start to a happy and fulfilled marriage.

As a student he had become interested in oral surgery and his first job after qualification was as House Surgeon. He then moved to Stoke Mandeville, where he remained for five years, during which time he passed the Fellowship and postgraduate orthodontic examinations. In 1959 he was recruited to join a growing staff at the School of Dentistry in Birmingham, initially as a Lecturer.

Don began to use transatlantic orthodontic techniques, long before they gained popular usage. Throughout the sixties and seventies he continually developed the Department of Children's Dentistry and Orthodontics in Birmingham. He was promoted successively to Senior Lecturer, Professor and Director of Dental Studies. His Textbook of orthodontics was a respected undergraduate textbook.

Don was always the same, whatever the time, person or place. Don treated everyone in a similar quiet, considerate way. I cannot recall him once speaking unkindly about anyone and conversely I cannot recall anyone saying bad things about him.

Don leaves his devoted wife Vera, children Michael, Martin and Susan; their wives and husband and seven grandchildren. He will be remembered with gratitude by his family, by all who worked with him, were taught by him, or were treated by him.

P. Rock 